Submission: 09.09.2020

Acceptance: 17.12.2020

\title{
On Galtung's Approach to Peace Studies
}

\begin{abstract}
On Galtung's Approach to Peace Studies
Abstract

Peace studies and research are fascinating because they delve into some of the quintessential questions concerning human relations, behavior, cooperation, and conflict. So how should we define peace at this point? Is a state-centered approach sufficient to explain peace independently, or should we include societies and individuals? The common tradition is to construct peace based on the concepts of conflict and violence, to produce norms and principles. In other words, the phenomenon of peace is conceived and discussed as a necessity. In this case, the question of "peace for and with whom" arises. Political science and the discipline of international relations are also insufficient to explain this debate. From this point of view, this study aimed to examine the general perspective of the pioneer theorist of peace studies, Johan Galtung, who combines theory and practice as much as possible and tries to define peace with the social realm processes with his unique thought infrastructure.
\end{abstract}

Keywords: Galtung, peace studies, negative-positive peace, conflict transformation

\author{
Galtung'un Barış Çalışmaları Üzerine \\ $\ddot{O} z$
}

Barış çalışmaları ve araştırmaları büyüleyicidir çünkü insan ilişkileri, davranış, iş birliği ve çatışmanın sonucu ile ilgili bazı önemli soruları incelemektedir. Peki bu noktada barış nasıl tanımlanmalıdır? Sadece devlet merkezli bir yaklaşım barışı açıklamak için yeterli midir yoksa toplumlar ve bireyler de dahil edilmeli midir? Ortak gelenek, barışı çatışma ve şiddet kavramlarını temelinde kurgulamak, normlar ve ilkeler üretmektir. Başka bir ifadeyle barış olgusu bir zorunluluk olarak kurgulanmakta ve tartışılmaktadır. Bu durumda "kim için ve kiminle barış" sorunsalını ortaya çıkmaktadır. Siyaset bilimi ve uluslararası iliş̧iler disiplini de bu tartışmayı açıklamada yetersiz kalmaktadır. Buradan hareketle teori ve pratiği mümkün olduğunca bir araya getiren ve kendine özgü düşünce altyapısıyla barışı toplumsal düzlem ve süreçlerle tanımlamaya çalışan barış çalışmaları alanının öncü kuramcısı Johan Galtung'un genel bakış açısını irdelemek bu araştırmanın amacını oluşturmaktadır.

Anahtar Sözcükler: Galtung, barış çalışmaları, negatifpozitif barış, çatışma dönüşümü

\section{Introduction}

Johan Galtung, who is regarded as the founder of peace studies, deserved this title with his extensive work and international efforts, which found a place for himself in the resolution of conflicts. It is possible to define Galtung as someone who inspires those who come after him in peace studies. Behind this inspiring power of Galtung is the work he has done since 1957. Galtung, who acts as a mediator in more than 150 conflicts worldwide, has 156 books, more than 1600 articles, and book chapters. He also founded "The International Peace Research Institute," the world's first on peace studies, in Oslo in 1959, "The Transcend International Foundation" in 1993, and the world's first online peace studies university known as "Transcend Peace University” in 2000 (Bilgin, 2018, pp. 175-176).

Besides peace studies, Galtung has researched human rights, sustainable development strategies, basic human needs, macrohistory, history of civilization, globalization, sociology, ecology, and the future. It is possible to understand his place in peace studies by focusing on the works in which Galtung contributed directly or indirectly to peace studies since his work is in an extensive scope. From this point of view, and considering his concern for bringing theory and practice together, it is possible to examine his work in the field of peace studies under two main

\footnotetext{
${ }^{1}$ Dr. Lecturer at Istanbul Yeni Yüzyıl University, Istanbul-TURKEY, burak.ercoskun@ yeniyuzyil.edu.tr, ORCID: 00000003-1163-3906
} 
headings. The first group includes studies on the theoretical framework and concepts. It is possible to consider his studies on the concepts of violence, conflict, and peace within this scope. In the other group, there are studies that directly include opinions and suggestions on how to resolve a particular conflict. Galtung has presented his views on resolving conflicts in various articles and books, from the Peru-Ecuador War in 1941 to the current Israeli-Palestinian conflict.

In addition to being the founder of peace studies, Galtung has a role in structuring peace studies over the years, as he handles his work in a wide frame and fuses it with other fields in social sciences. Galtung rightly assumed this role with his work based on the concern of how to establish lasting peace. In this context, it is necessary to mention the concepts of violence and peace, which are the basis of his studies up to now, and the forms he has brought to these concepts. Later, giving his views on the structure and resolution of the conflict will make it easier to consider Galtung in terms of integrity.

\section{Defining violence}

In his article titled "Violence, Peace and Peace Research, " published in 1969, Galtung stated that while revealing the relationship between violence and peace, it is necessary to define violence first (Galtung, 1969, pp. 167-168). In this context, he defines violence as the effects applied to people to fall behind their physical and mental potentials and draws a wide-ranging framework from economic inadequacies to wars, from ideological pressures to threats. He also explains his views on violence comprehensively by emphasizing the difference between forms of violence while focusing on physical and psychological violence on the one hand and the presence of an object and what or who the subject is on the other.

According to Galtung, violence is any avoidable assault on basic human needs. The basic needs of people are survival, well-being, freedom, and identity. The threat of violence against these basic human needs can also be defined as violence because individuals can establish a meaningful relationship with their environment only by meeting their basic needs. This relationship with the environment can also be at an emotional and spiritual level outside of the physical level (Galtung, 2009, pp. 2-5).

Galtung, who developed his views on violence based on his work in 1969, divides violence into direct, structural, and cultural violence. The connection of three types of violence with each other is shown in Figure 1.

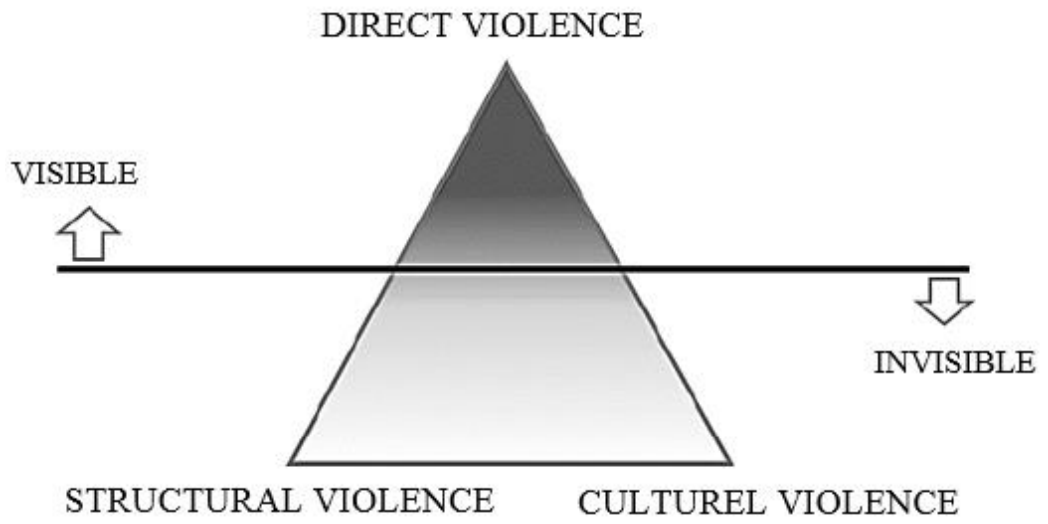

Figure 1. Galtung's Violent Triangle Model

Source: Galtung (1990, p. 295) 
According to this distinction, Galtung states that structural violence is caused by political mechanisms, processes, and institutions that ensure the satisfaction of identity, reputation, and security needs. In contrast, cultural violence is fed by anger, fear, and hatred that arise from the parties' not understanding or misunderstanding each other. According to Galtung (2004, p. 18), structural and cultural violence is the source of invisible conflicts; this violence directly turns into violence and becomes visible. In this context, conflict is a variable process in which structural, cultural, and direct violence affect each other.

Galtung's views on violence form the basis of his views on the concept of peace. Especially the connection he establishes between the direct, structural, and cultural relationship of violence and the concept of peace is essential. Thus, understanding violence becomes a prerequisite for achieving peace.

\section{Negative and Positive Peace}

One of the most widely accepted definitions in the discipline of international relations is Galtung's concept of peace. In his study "What is peace research?” published in 1964, Galtung describes negative peace as the absence of human violence and war, positive peace as the absence of structural violence (Galtung, 1964, pp. 1-4). It is possible to say that Galtung's views on negative and positive peace developed and matured over time, as in the concept of violence. As a matter of fact, in this first attempt to define peace, he could not convey what should be understood when positive peace is mentioned.

By 1967, Galtung, who shaped his views on negative and positive peace a little more, defines negative peace as the absence of organized, collective violence between large groups of people such as nations and even between classes, races, and ethnic groups. While making this definition, he points out that violence is a problematic concept and states that the violence meant in defining negative peace is based on physical force. However, according to him, negative peace is insufficient. The main thing is to achieve positive peace by going beyond the state of negative peace. In this context, positive peace is defined as cooperation and integration between human societies (Galtung, 1967, p. 14). In 1969, he established a relationship between positive peace and structural violence. Accordingly, violence has two sides, namely personal and structural, and this expanding structure of the concept of violence has also expanded the concept of peace. In this context, he emphasizes that the absence of personal violence cannot cause positive violence and expresses the necessity of the absence of structural violence in the issue of positive violence (Galtung, 1969, p. 183).

Over time, Galtung further developed the relationship between peace and violence, making this relationship the basic structure in resolving conflicts. In 1981, he stated that the powerful used the concept of peace in order to protect the status quo in society and stated that the concept of peace should be enriched (Galtung, 1981, p. 183). Based on this, Galtung argued that ideas such as fair war are exploited by leaders and argues that peace should be achieved by peaceful means (Galtung, 1985, pp. 141-142). He also introduced the concept of "cultural violence" and stated that this concept was used to justify direct and structural violence (Galtung, 1990, p. 291). Thus, it emphasizes the absence of different forms of violence for the existence of peace.

On the other hand, according to him, there is a situation of testing positive peace. Cooperation between the parties, cultural freedom, peace movements is directly involved in the face of violence. The existence of fairness, equality, development and cultural coexistence, instead of structural violence, creates the appropriate conditions for positive peace. Instead of cultural violence, the existence of an understanding rooted in humanist art, democracy and human rights shows that positive peace can be achieved (Galtung, 1996, p. 33). 
Negative and positive peace also forms the basis of Galtung's concept of peacebuilding, which he first addressed in 1976. According to Galtung, peace should be built after the problems caused by structural violence are eliminated, so positive peace should be targeted, not negative peace (Galtung, 1976, pp. 297-298). Therefore, it constitutes the fulcrum for lasting and sustainable peacebuilding by emphasizing the end of violence instead of preventing or resolving conflicts.

\section{The Nature of the Conflict}

Galtung defines conflict as a dynamic process in which structure, attitudes, and behaviors continuously change and affect each other (Galtung, 1958, p. 24). According to him, to understand the basic logic of conflict, it is necessary to start from the idea that individuals and groups have interests. For example, the aims of two states that want the same region may sometimes be incompatible with each other. When two goals are incompatible with each other, there is a contradiction, in which case a conflict arises. The parties feel tension because of the goals they cannot realize, and this tension turns into hate and creates an attitude. This attitude manifests itself as aggression, hatred, or verbal and physical violence. Ultimately, violence and hatred that arise to protect, achieve, or destroy goals turn into conflict.

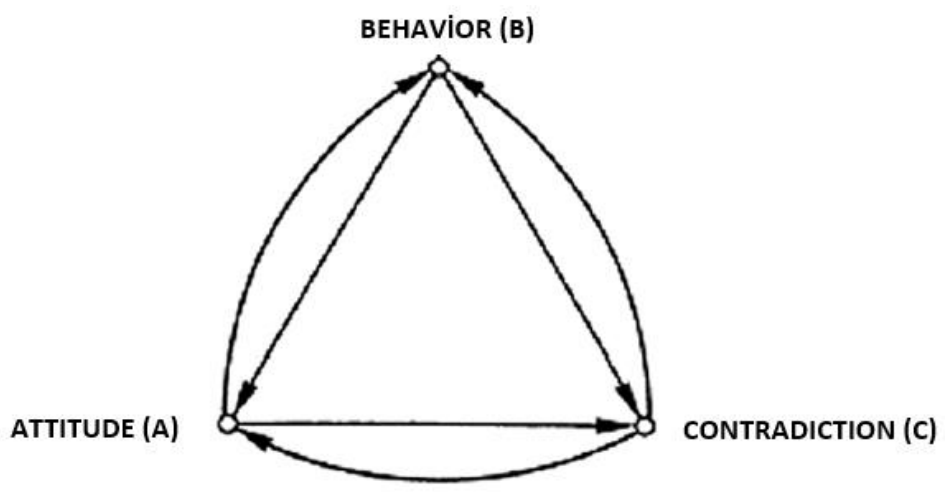

Figure 2. The Conflict Triangle

Source: Galtung (1996, p. 72)

In this model developed by Galtung and also known as the $\mathrm{ABC}$ triangle, the attitude refers to the psychological conditions and feelings of stakeholders such as religious and ethnic hatred, fear of losing power, and unfavorable prejudices. Behavior includes actions that are positive or negative. The contradiction refers to the general situation in political, economic, and social terms, such as allocating scarce resources, land disputes, or unequal political representation. Behavior is observable and experienced, while attitude and contradiction are veiled, and only inference can be made (Galtung, 1996, pp. 71-72). On this basis, Galtung deepens his analysis of the nature of the conflict with concepts such as actor, purpose, conflict, and pursuit.

\section{Life Cycle of Conflict}

According to Galtung, conflicts consist of various stages, including interrelated pre-violence, a period of violence, and post-violence processes, and show different characteristics in these processes. In other words, the intensity level of conflicts, which have a dynamic structure rather than being monotonous and static, changes during the process. Understanding the conflict cycle is essential to prevent and manage conflict and determine how, where, and when to implement strategies and measures. According to him, what needs to be done to turn the conflict into peace can be put forward according to these stages (Galtung, 2000, p. 2). 
Galtung describes the life cycle of the conflict with a diagram that he classifies temporally and conceptually, as in Figure 3.

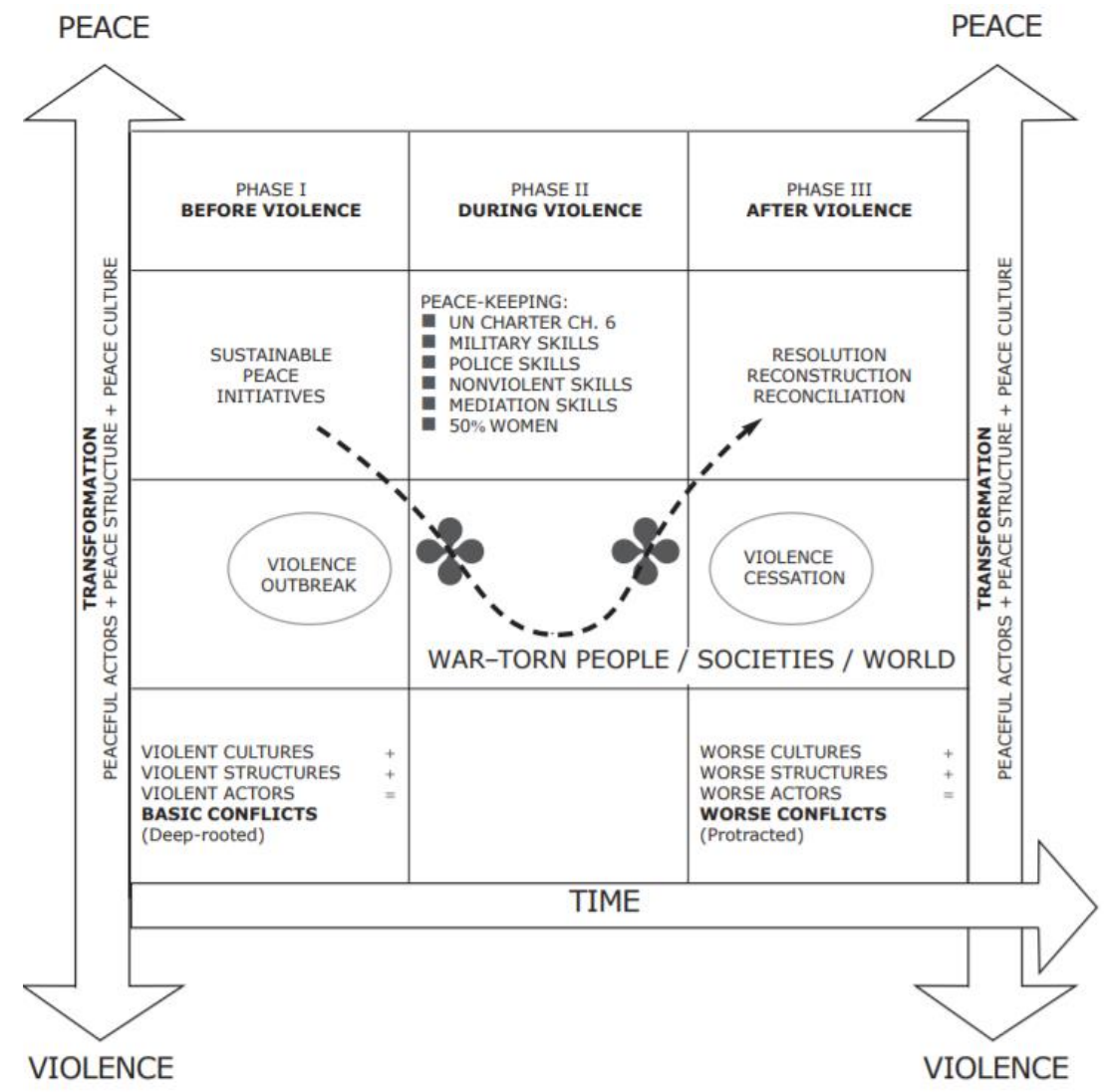

Figure 3. Life-cycle of conflict

Source: Galtung (2000, p. 2)

Even if there is no violence, there is conflict in the stage before violence. In the first stage, there is a culture of violence that legitimizes violence, actors who seek to gain power with a structure that oppresses and exploits people. Therefore, violence is likely to occur. Steps should be taken to resolve the conflict with empathy, creativity, and nonviolence. Failing at this first stage causes the conflict to turn into a violent form. The second stage is the violence stage. The first thing to do here is to stop the violence. No violence lasts forever. However, it is not right to expect violence to end spontaneously. The best move to eliminate violence is to use peaceful means. Violence should be prevented with the peace missions to be established within the framework of Chapter 6 of the UN Charter or the structures where women will dominate. After the violence is ended, the third stage is started. However, what needs to be done at this stage is more complicated than others. Because post-violence traumas or a sense of revenge; can make culture, structure, and actor more prone to violence. Therefore, the first thing that needs to be done is to reconstruct the material losses, reach a consensus on the subject of the conflict, and resolve the central issue underlying the conflict in structural and cultural dimensions. Unless these are done, the first stage is passed again (Galtung, 2000, pp. 2-8). Galtung's life cycle is considered the basis of the approach of resolving conflicts by the transformation. 


\section{Transforming Conflict}

Conflict transformation aims to change the differences of individuals and communities through win-win (collaborative) problem-solving. It consists of structural change-oriented and long-term peace-oriented studies. Conflict is a never-ending process because its nature and manifestations change (Galtung, 1996, pp. 89-90). Therefore, conflict transformation is carried out at multiple levels to develop the understanding and skills that empower all those who coexist peacefully together in the long term, conflict, and its actors.

Conflict transformation; aims to change or transform the events, people, and relationships that create it when a conflict occurs. Conflict transformation; includes changes made in the conflict's personal, structural, relational, and cultural aspects. Overcoming fear and insecurity, removing misperceptions, and learning to communicate effectively are essential elements to redefine relationships between parties in conflict and contribute to establishing justice and equality. The conflict transformation approach introduced by Galtung in 1998 is expressed as the transcend method and has become popular since the early 2000s. Galtung developed this method inspired by the diagnosis, prognosis, and treatment (DPT) process of a disease. In this context, the method determines the source of the conflict, revealing possible scenarios regarding its course, and making the necessary interventions to reduce the violence (Galtung, 2000, p. 5). For some, this approach represents the deepest level of resolution. For others, it is an important step beyond the resolution of the conflict because it reflects a deeper understanding of the nature of the conflict than any other approach and works towards a long-term sustainable positive peace.

\section{Conclusion}

It is seen that Galtung, who is known as the founder of the field of peace studies, deals with the concepts of violence, peace, and conflict with the concern of establishing lasting peace from the very beginning and with a different reading. He focuses on the typology of violence, negative-positive peace distinction, conflict cycle, and conflict transformation, and that he fuses his studies with other fields in social sciences and is a source of inspiration for other researchers proves this situation. Also; It is possible to say that the theoretical views on the definition of peace, what can be evaluated under the concept of conflict, and how to resolve conflicts permeate all these studies on practical issues.

Although he sometimes only includes theoretical discussions in his works, it can be said that his main concern is the effort to bring theory and practice together and transfer them to the reader. However, it is impossible to find a general flow of topics, as Galtung's works are spread over a broad period. Galtung can reconsider a subject and concept that he previously dealt with, later in his work in a different field. Because his approaches to concepts or events matured over time, he revealed the concepts and facts he dealt with in the early years in new forms in his recent studies. This also stems from the fact that "coming to terms with peacebuilding necessitates a wholesome transformation in methodological and practical realms together with examining its evolution throughout the history of political thought" (Ercoşkun and Konuralp, 2020, p. 188). This sometimes makes it challenging to consider the views he has put forward in his work in integrity. On the other hand, it should not be interpreted as there is an inconsistency in these studies, but rather as trying to include the concepts and the views he put forward consistently in different platforms and case studies. As a result, Galtung's point of view is useful in discussing the concept of peace as a reality, not a longing. 


\section{References}

Bilgin, K. (2018). Johan Galtung. Barış Çalışmaları in (pp. 175-207). Ankara: Adres Yayınları.

Ercoşkun, B , Konuralp, E . (2020). Change, Transformation, and Trends in Peace Studies . Dumlupınar Üniversitesi Sosyal Bilimler Dergisi, (66) , 187-199 . Retrieved from https://dergipark.org.tr/tr/pub/dpusbe/issue/57463/739123

Galtung, J. (1964). 'What is peace research?' Journal of Peace Research, 1(1), 1-4.

Galtung, J. (1967). Theories of Peace: A Synthetic Approach to Peace Thinking. Oslo: International Peace Research Institute.

Galtung, J. (1969). Violence, Peace and Peace Research. Journal of Peace Research, 6(3), 167-191.

Galtung, J. (1981). Social Cosmology and the COncept of Peace. Journal of Peace Research, 17(2), 183-199.

Galtung, J. (1985). Twenty five years of Peace Research: Ten Challenges and Some Responses. Journal of Peace Research, 22(2), 141-158.

Galtung, J. (1990). Cultural Violence. Journal of Peace Research, 27(3), 291-305.

Galtung, J. (1996). Peace by Peaceful Means: Peace and Conflict, Development and Civilization. London: Sage.

Galtung, J. (2000). Conflict Transformation by Peaceful Means (The Transcend Method). New York.

Galtung, J. (2004). Violence, war, and their impact: On visible and invisible effects of violence. Forum for Intercultural Philosophy, 5, 12-32.

Galtung, J. (2009). Çatışmaları Aşarak Dönüş̧ürmek: Çatışma Çözümüne Giriş. Ankara: Usak Yayınları. 
